\title{
ORIGINALARTICLE
}

\section{INDICATORS OF MORBIDITY AND MORTALITY BY FEMUR FRACTURES IN OLDER PEOPLE: A DECADE-LONG STUDY IN BRAZILIAN HOSPITALS}

\author{
INDICADORES DE MORBIDADE E MORTALIDADE \\ POR FRATURAS DE FÊMUR EM IDOSOS: ANÁLISE DE \\ UMA DÉCADA EM HOSPITAIS BRASILEIROS
}

\author{
Viviane Cristina Uliana Peterle ${ }^{1}$ (i), João Carlos Geber Junior ${ }^{2}$ (1), Willian Darwin Junior ${ }^{3}$ (1), \\ alexandre Vasconcelos Lima ${ }^{4}$ (i), Paulo Emillano Bezerra Junior ${ }^{5}$ (i), Maria Rita Carvalho Garbi Novaes ${ }^{1}$ (i) \\ 1. Universidade de Brasília, Brasília, DF, Brazil. \\ 2. Hospital Alvorada Brasília, Medical Clinic Department, Brasília, DF, Brazil. \\ 3. Universidade de São Paulo, São Carlos School of Engineering, Department of Electrical and Computer Engineering, São Carlos, SP, Brazil. \\ 4. Instituto Brasileiro de Segurança de Trânsito, Brasília, DF, Brazil. \\ 5. Escola Superior de Ciências da Saúde, Brasília, DF, Brazil.
}

\section{ABSTRACT}

Objective: To evaluate the profile of femur fractures in older adults in Brazil between 2008 and 2018. Methods: Population-based time series study with data from the Department of Informatics of the Unified Health System (Datasus), including 480,652 hospitalizations, of adults from 60 years and over, with hip fracture (ICD10-S72). Results: There was an increase of $76.9 \%$ in the hospitalization register (mean 5.87\%/year) and an average incidence rate of 19.46 fractures for every 10,000 older adults. In total, $68 \%$ of hospitalizations were female, $28 \%$ from São Paulo. The average length of stay was 8.9 days, being higher in the Northern Region (11.8) and in the Federal District (18.7). Average mortality rate was $5 \%$, being higher in men $(5.45 \%)$ and over 80 years old. Northeast Region had the lowest mortality rate (3.54\%). Southeast Region had the highest rate (5.53\%). Total cost of hospitalizations was $\mathrm{R} \$ 1.1$ billion, with an average of $\mathrm{R} \$ 100$ million/year. Average cost per hospitalization was higher in the Southern Region ( $\mathrm{R} \$ 2,491.00)$. Conclusion: Femoral fracture is an important cause of mortality among older adults, with a higher incidence in women but higher mortality in men, with high cost to the system and regional differences. Level of Evidence II, Economic and decision analyses - developing an economic or decision model.

Keywords: Femur. Aged/Mortality. Risk Factors. Health Systems. Osteoporosis.

\section{RESUMO}

Objetivo: Avaliar o perfil das fraturas de fêmur em idosos no Brasil no período de 2008 a 2018. Métodos: Estudo de série temporal baseado em dados do Departamento de Informática do Sistema Único de Saúde (Datasus), incluindo 480.652 internações de pessoas com idade a partir de 60 anos e com fratura de quadril (ICD10-S72). Resultados: Houve aumento de 76,9\% no registro de hospitalização (média de 5,87\% por ano) e taxa de incidência média de 19,46 fraturas para cada 10 mil idosos. O estado de São Paulo respondeu por $28 \%$ do total de registros, e as internações de pacientes do sexo feminino corresponderam a $68 \%$ do total. O tempo médio de permanência foi de 8,9 dias, com maiores índices na Região Norte $(11,8)$ e no Distrito Federal $(18,7)$. A taxa média de mortalidade foi de $5 \%$ e atingiu os maiores valores entre os homens $(5,45 \%)$ e os pacientes com mais de 80 anos. A região Nordeste apresentou a menor taxa de mortalidade $(3,54 \%)$ e a região Sudeste teve a maior (5,53\%). O custo total das internações foi de $R \$ 1,1$ bilhão, com média de $R \$ 100$ milhões ao ano. O custo médio por hospitalização foi maior na região Sul $(R \$ 2.491,00)$. Conclusão: A fratura do fêmur é importante causa de mortalidade em idosos, com maior incidência em mulheres e maior mortalidade em homens, alto custo para o sistema e diferenças regionais. Nível de Evidência II, Análises econômicas e de decisão desenvolvimento de modelo econômico ou de decisão.

Descritores: Fêmur. Idoso/Mortalidade. Fatores de Risco. Sistemas de Saúde. Osteoporose.

Citation: Peterle VCU, Geber JC Jr, Darwin W Jr, Lima AV, Bezerra PE Jr, Novaes MRCG. Indicators of morbidity and mortality by femur fractures in older people: a decade-long study in brazilian hospitals. Acta Ortop Bras. [online]. 2020;28(3):142-8. Available from URL: http://www.scielo.br/aob.

All authors declare no potential conflict of interest related to this article. 


\section{INTRODUCTION}

Although the aging process is more advanced in Europe and North America, where one in five people were 60 or older in 2017, populations in other regions are also aging. By 2050, older adults are expected to account for $35 \%$ of the population in Europe, $28 \%$ in North America, $25 \%$ in Latin America and the Caribbean, $24 \%$ in Asia, 23\% in Oceania and 9\% in Africa. ${ }^{1}$

The Brazilian Institute of Geography and Statistics (IBGE), based on projection models, estimated that $13 \%$ of the population was 60 or older in 2018, which corresponds to 19.2 million. However, by 2060 , the country will have more older than younger people. ${ }^{2}$ The association between longevity and the prevalence of chronic diseases is described in the literature. ${ }^{3}$ In the United States, about half (50.9\%) of adults have at least one chronic condition and $26 \%$ have two or more conditions. ${ }^{4} \mathrm{~A}$ study with data from the National Health Survey (PNS), held in 2013 in Brazil, revealed that the prevalence of three simultaneous diseases in the age group 60 and older was 3.7 times the prevalence in the 35-59 age group, and almost 20 times the prevalence of those between 18 and 34 years old. ${ }^{5}$

Insufficient muscle function and poor physical performance are also strong predictors of clinically relevant adverse events in older adults. ${ }^{6}$ These factors corroborate the falls, which, may predict future fractures when frequent, in addition to the likelihood of associated risk factors. ${ }^{7}$ Regarding hip fractures, they are a useful substitute to determine the burden of osteoporosis. Although they may account for less than $20 \%$ of all osteoporotic fractures, hip fractures account for most fracture-related health care due to high morbidity, mortality, and hospitalization costs. ${ }^{8,9}$

Determination of the individual hip fracture incidences in several countries and even in many locations within the same country has shown great variability in rates, leading to the suspicion of several factors that explain such differences, mainly the genetic, climatic, ethnic-cultural, anthropometric and geographic ones. Tools like $F R A X^{\circledR}$, specific to each country and based on national epidemiological studies, from clinical risk factors (CRF), with or without bone mineral density (BMD), may provide the likelihood of fracture of the femur and other bones over the next 10 years. ${ }^{10}$ Based on the perspective of population aging as a consequence of the individual aging process, our study sought to analyze the panorama of health services utilization through the registration of femur fracture in Brazilian older adults between 2008 and 2018. Our study seeks to identify sociodemographic characteristics and the profile of assistance to users, represented by the differences between the hospitalizations of the analyzed localities to collaborate to guide regional policies for prevention and to promote the best allocation of services offer.

\section{METHODS}

This is a descriptive study, population-based, in time series, from public domain data and provided by the Hospital Information System of the Unified Health System (SIH/SUS), through health information (Tabnet). It was enabled by the Health Surveillance Secretariat of the Ministry of Health, through the electronic portal of the Department of Informatics of the Unified Health System (Datasus), extracted between June 9th and June 11th, 2019 (http://www.datasus.gov.br). The system database is generated through hospital units (public and private publicly funded) that send the information of hospitalizations made through the Authorization of Hospital Admission $(\mathrm{AlH})$ for Municipal and State management. Such information is processed by the Datasus and form an extensive database with hospital information from all over the Brazilian territory.
The filters referring to hospital morbidity data related to femur fracture were applied, without distinction of anatomical location, referring to the 10th International Classification of Diseases review (ICD-10 S72), in patients aged 60 years or older, between 2008 and 2018 in Brazil. The variables analyzed were: number of hospitalizations, age groups, sex, total and average cost per hospitalization, average number of days of hospital stay, deaths and mortality rate. Variables such as race, type of care and funding were not considered for analysis due to the considerable percentage of ignored records. Data were presented descriptively, proportionally and analyzed as coefficients and rate when possible.

The hospital mortality coefficient for femur fracture was obtained by the ratio between the number of deaths from femur fracture by the total number of hospitalizations for this diagnosis in the same age group as the patients.

Hospitalization rate in older adults due to femur fracture was obtained by the ratio between the number of hospitalizations due to femur fracture in people aged 60 years or older, by place of residence and total population aged 60 and over, in the same period and place considered in the numerator, using the database of the Brazilian Institute of Geography and Statistics (IBGE) referring to population projections.

The cost projection was performed using triple time series exponential smoothing analysis, Holt-Winters. Projections were made until the year 2028.

Our study supports a regional study conducted with secondary data on the subject and was approved by the Research Ethics Committee under number CAAE: 89658718.8.0000.5553

\section{RESULTS}

Between January 2008 and December 2018, 480,652 hospitalizations for femur fracture were recorded in the population over 60 years old in Brazil, accounting for $2.5 \%$ of all hospitalizations for this age group, in both sexes. In the same period, hospitalizations record increased by $76.9 \%$, an average increase of $5.87 \%$ per year, as shown in Figure 1. Considering the IBGE annual projections for the population, the average hospitalization rate in the age group over 60 years old due to femur fracture over 10 years, for both sexes, was 19.46 for every 10,000 older adults in Brazil.

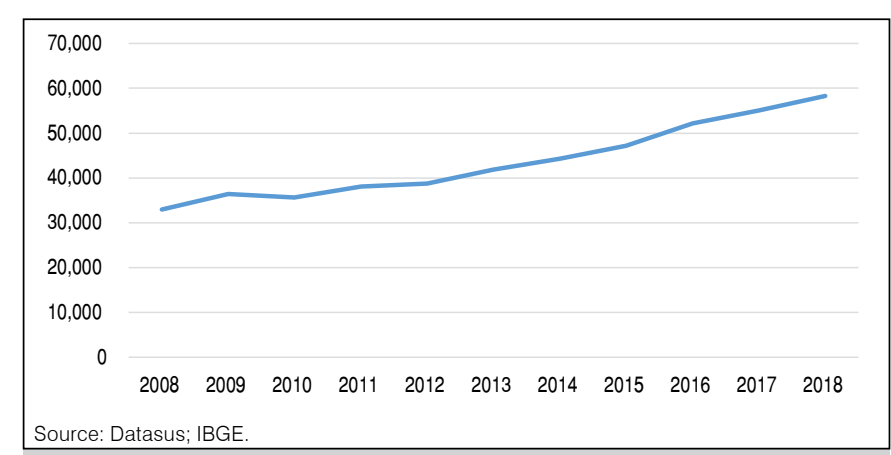

Figure 1. Number of hospitalizations for femur fracture in Brazil, older adults over 60 years old, between 2008 and 2018.

The number of femoral fracture records was higher among women, who represent $68 \%$ of total hospitalizations. The result is a female/ male hospitalization ratio of 2.1/1. Regarding the age groups over 60 years old, the analysis shows a sustained increase of hospitalization due to femur fracture with age progression for both sexes, and the population from 80 years old and over accounts for $47.5 \%$ of the patients, increasing the hospitalization ratio between women/men in this age group to 2.9/1. 
The average length of hospital stay for femur fracture in Brazil was 8.9 days for both sexes. However, there was a slight predominance of more days of hospitalization in the male population for all age groups. Between 2008 and 2018, considering the ICD S72 in the population over 60 years old, for both sexes, 24,027 deaths were recorded in Brazil, representing an average mortality rate of $5 \%$, estimated by the ratio between the number of deaths and the number of hospitalizations in this population over 60 years old due to femur fracture.

We observed a predominance of the male population in the average mortality rate (5.45\%), in all age groups above 60 years old, which represents a male/female death ratio of 1.13/1, and an ascending pattern. Mortality rate among men above 80 years old was 4.6 higher than among the age group of 60 to 64 years, representing a variation of $38.9 \%$. In women, the variation in mortality between these age groups is smaller (31.4\%), with a rate 3.81 times greater when 80 years, as shown in Table 1.

The total cost of hospitalizations from 2008 to 2018 in Brazil was $\mathrm{R} \$ 1.1$ billion, with an average of $\mathrm{R} \$ 100$ million/year. The cost analysis reveals an increase of $158 \%$ in the period from 2008 to 2018 , which represents $9.14 \%$ per year. The average value of each hospitalization was $R \$ 2,290.80(R \$ 1,781.62-R \$ 2,602.18)$, and $80 \%$ of the total cost focused on the age group of 70 years old, regardless of sex, as shown in Table 2.

The estimated cost projection analysis for the next decade (2019-2028) is $\mathrm{R} \$ 2.16$ billion, $107.0 \%$ over than the period studied, as shown in Figure 2.

Table 1. Number of hospitalizations, average length of stay, deaths and mortality rate, total by age group and by sex, between 2008 and 2018.

\begin{tabular}{|c|c|c|c|c|c|}
\hline Sex & Age Group & $\begin{array}{c}\text { Number of } \\
\text { Hospitalizations }\end{array}$ & $\begin{array}{l}\text { Average length } \\
\text { of stay (days) }\end{array}$ & Deaths & Mortality Rate (\%) \\
\hline \multirow{6}{*}{ Total } & Total & 480,652 & 8.9 & 24,027 & 5.00 \\
\hline & 60 to 64 & 43,834 & 8.9 & 804 & 1.83 \\
\hline & 65 to 69 & 52,587 & 8.9 & 1,269 & 2.41 \\
\hline & 70 to 74 & 68,129 & 8.8 & 2,027 & 2.98 \\
\hline & 75 to 79 & 87,761 & 8.8 & 3,405 & 3.88 \\
\hline & 80 and over & 228,341 & 8.9 & 16,522 & 7.24 \\
\hline \multirow{6}{*}{ Male } & Total & 153,608 & 9.0 & 8,368 & 5.45 \\
\hline & 60 to 64 & 22,662 & 9.1 & 435 & 1.92 \\
\hline & 65 to 69 & 22,325 & 9.1 & 596 & 2.67 \\
\hline & 70 to 74 & 23,758 & 9.0 & 846 & 3.56 \\
\hline & 75 to 79 & 26,224 & 9.0 & 1,239 & 4.72 \\
\hline & 80 and over & 58,639 & 9.0 & 5,252 & 8.96 \\
\hline \multirow{6}{*}{ Female } & Total & 327,044 & 8.8 & 15,659 & 4.79 \\
\hline & 60 to 64 & 21,172 & 8.7 & 369 & 1.74 \\
\hline & 65 to 69 & 30,262 & 8.8 & 673 & 2.22 \\
\hline & 70 to 74 & 44,371 & 8.7 & 1,181 & 2.66 \\
\hline & 75 to 79 & 61,537 & 8.8 & 2,166 & 3.52 \\
\hline & 80 and over & 169,702 & 8.8 & 11,270 & 6.64 \\
\hline
\end{tabular}

Source: Datasus.

Table 2. Number of hospitalizations, cost of hospitalization and average value per total hospitalization between 2008 and 2018 and per year of processing.

\begin{tabular}{c|c|c|c}
\hline $\begin{array}{c}\text { Year } \\
\text { Processing }\end{array}$ & $\begin{array}{c}\text { Hospitalizations } \\
\text { (n) }\end{array}$ & Cost (R\$) & $\begin{array}{c}\text { Average Value } \\
\text { Hospitalization } \\
\text { (R\$) }\end{array}$ \\
\hline $\begin{array}{c}\text { Total } \\
\mathbf{( 2 0 0 8 - 2 0 1 8 )}\end{array}$ & $\mathbf{4 8 0 , 6 5 2}$ & $\mathbf{1 , 1 0 1 , 0 7 2 , 8 7 2 . 2 4}$ & $\mathbf{2 , 2 9 0 . 7 9}$ \\
\hline 2008 & 32,950 & $58,704,215.87$ & $1,781.62$ \\
\hline 2009 & 36,435 & $69,269,677.41$ & $1,901.19$ \\
\hline 2010 & 35,620 & $72,767,862.66$ & $2,042.89$ \\
\hline 2011 & 38,119 & $78,749,699.25$ & $2,065.89$ \\
\hline 2012 & 38,755 & $82,170,390.49$ & $2,120.25$ \\
\hline 2013 & 41,874 & $97,259,762.36$ & $2,322.68$ \\
\hline 2014 & 44,316 & $107,536,595.16$ & $2,426.59$ \\
\hline 2015 & 47,138 & $114,839,321.03$ & $2,436.24$ \\
\hline 2016 & 52,130 & $129,496,301.52$ & $2,484.10$ \\
\hline 2017 & 55,034 & $138,627,352.66$ & $2,518.94$ \\
\hline 2018 & 58,281 & $151,651,693.83$ & $2,602.08$ \\
\hline
\end{tabular}

Source: Datasus.

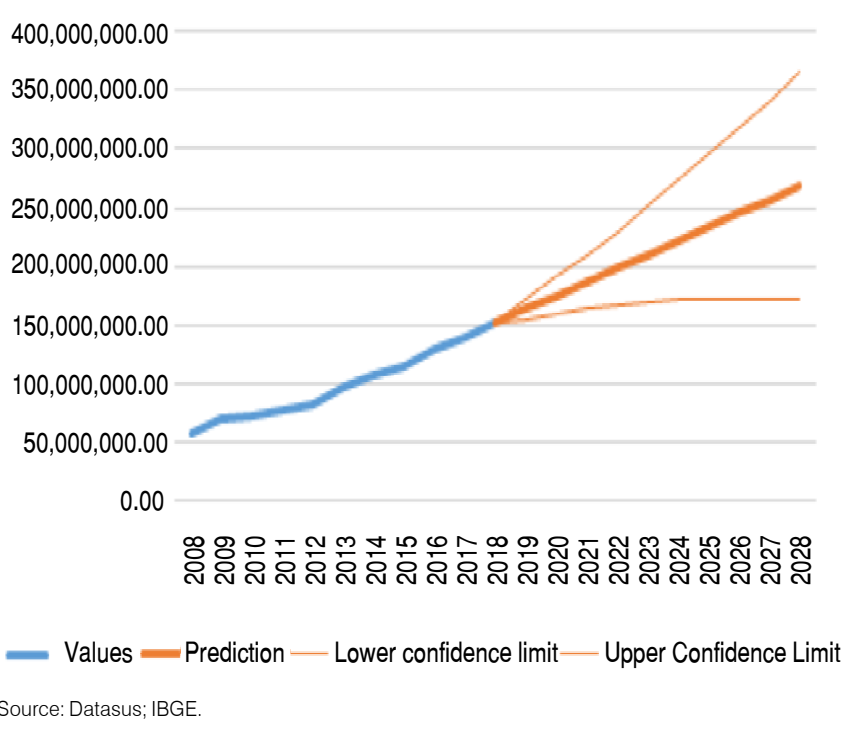

Figure 2. Cost projection for femur fracture in Brazil, over 60 years old, between 2008 and 2018 
Regarding demographic analysis, Table 3 shows an overview of the Brazilian scenario between 2008 and 2018. Considering the five regions of the country, the number of hospitalizations records for femur fractures in the same period and age groups over 60 years old, in both sexes, predominated in the southeast region (53.1\%).

The state of São Paulo stands out with 136,402 hospitalizations, which represents $28 \%$ of the records for femur fracture in Brazil. Roraima (RR) was the state with the lowest hospitalization for femur fracture, with 495 records in 10 years, as shown in Figure 3. Almost half of the Brazilian states (Rondônia, Amazonas, Amapá, Tocantins, Maranhão, Ceará, Paraíba, Sergipe, Bahia, Espírito Santo, Rio de Janeiro and the Federal District) has twice the average national hospitalization time, especially
Amapá (19.5 days), Rondônia (19.2 days) and Federal District (18.7 days), reaching twice the national average (8.9 days).

The Northeast Region had the lowest mortality rate due to femur fracture in Brazil, between 2008 and 2018, with 3.54\% of deaths, considering all age groups of 60 years old and over. Ceará had the lowest proportion between the number of deaths and the number of hospitalizations, with a $2.37 \%$ rate in the study period. It was followed by the state of Alagoas (2.53\%), which also had the lowest average hospital stay in Brazil (6.5 days), and the state of Paraíba with 2.99\% of deaths, regardless of age group or sex, representing almost half of the national average of $5 \%$. In the overall average for the period, the Southeast Region had the highest mortality rate (5.53\%) in Brazil, featured for the state of Rio de Janeiro (6.08\%), as shown in Table 4.

Table 3. Number of hospitalizations, cost, average length of stay, deaths and mortality rate, total by region, between 2008 and 2018 .

\begin{tabular}{|c|c|c|c|c|c|c|}
\hline \multirow{2}{*}{ Region } & \multirow{2}{*}{$\begin{array}{l}\text { Hospitalizations } \\
\text { (n) }\end{array}$} & \multirow{2}{*}{$\begin{array}{l}\text { Total Cost } \\
\text { (R\$) }\end{array}$} & \multirow{2}{*}{$\begin{array}{c}\text { Average } \\
\text { hospitalization } \\
\text { cost }(\mathrm{R} \$)\end{array}$} & \multirow{2}{*}{$\begin{array}{l}\text { Average length } \\
\text { of stay ( days ) }\end{array}$} & \multirow{2}{*}{$\begin{array}{l}\text { Deaths } \\
\text { (n) }\end{array}$} & Mortality Rate \\
\hline & & & & & & $(\%)$ \\
\hline Total & 480,652 & $1,101,072,872.24$ & $2,290.79$ & 8.9 & 24,027 & 5 \\
\hline North Region & 17,870 & $39,110,174.72$ & $2,188.59$ & 11.8 & 692 & 3.87 \\
\hline Northeast Region & 88,452 & $188,705,323.81$ & $2,133.42$ & 9.6 & 3,130 & 3.54 \\
\hline Southeast Region & 255,097 & $587,449,632.96$ & $2,302.85$ & 8.8 & 14,082 & 5.52 \\
\hline South Region & 90,512 & $225,474,745.18$ & $2,491.10$ & 7.8 & 4,816 & 5.32 \\
\hline Midwest Region & 28,721 & $60,332,995.57$ & $2,100.66$ & 9.1 & 1,307 & 4.55 \\
\hline
\end{tabular}

Source: Datasus.

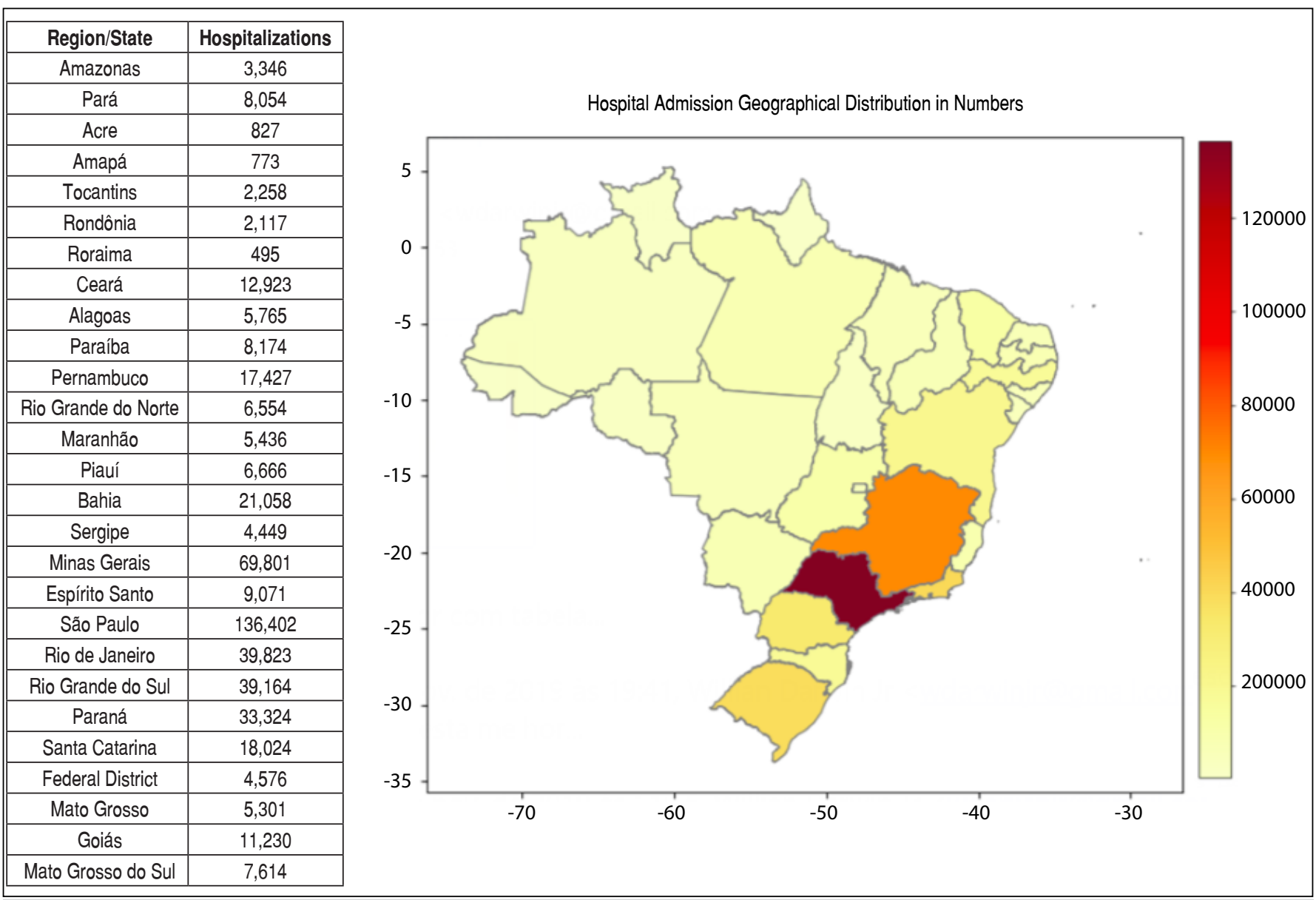

Figure 3. Number of hospitalizations due to femur fractures in patients over 60 years old by Brazilian state between 2008 and 2018. 
Table 4. Number of hospitalizations, average length of stay, deaths and mortality rate, total by region/state, between 2008 and 2018.

\begin{tabular}{|c|c|c|c|c|}
\hline Region/State & Hospitalizations & Average length of stay (days) & Deaths & Mortality Rate (\%) \\
\hline TOTAL & 480,652 & 8.9 & 24,027 & 5.00 \\
\hline North Region & 17,870 & 11.8 & 692 & 3.87 \\
\hline Amazonas & 3,346 & 14.1 & 111 & 3.32 \\
\hline Pará & 8,054 & 8.7 & 277 & 3.44 \\
\hline Acre & 827 & 8.9 & 34 & 4.11 \\
\hline Amapá & 773 & 19.5 & 35 & 4.53 \\
\hline Tocantins & 2,258 & 11.4 & 105 & 4.65 \\
\hline Rondônia & 2,117 & 19.2 & 105 & 4.96 \\
\hline Roraima & 495 & 8.5 & 25 & 5.05 \\
\hline Northeast Region & 88,452 & 9.6 & 3,130 & 3.54 \\
\hline Ceará & 12,923 & 10.3 & 306 & 2.37 \\
\hline Alagoas & 5,765 & 6.5 & 146 & 2.53 \\
\hline Paraíba & 8,174 & 10.1 & 244 & 2.99 \\
\hline Pernambuco & 17,427 & 9.7 & 548 & 3.14 \\
\hline Rio Grande do Norte & 6,554 & 8.0 & 211 & 3.22 \\
\hline Maranhão & 5,436 & 10.5 & 190 & 3.50 \\
\hline Piauí & 6,666 & 7.9 & 261 & 3.92 \\
\hline Bahia & 21,058 & 9.9 & 920 & 4.37 \\
\hline Sergipe & 4,449 & 11.9 & 304 & 6.83 \\
\hline Southeast Region & 255,097 & 8.8 & 14,082 & 5.52 \\
\hline Minas Gerais & 69,801 & 7.3 & 3,165 & 4.53 \\
\hline Espírito Santo & 9,071 & 10.4 & 482 & 5.31 \\
\hline São Paulo & 136,402 & 7.8 & 8,015 & 5.88 \\
\hline Rio de Janeiro & 39,823 & 14.2 & 2,420 & 6.08 \\
\hline South Region & 90,512 & 7.8 & 4,816 & 5.32 \\
\hline Rio Grande do Sul & 39,164 & 8.7 & 1,699 & 4.34 \\
\hline Paraná & 33,324 & 6.8 & 1,946 & 5.84 \\
\hline Santa Catarina & 18,024 & 8.0 & 1,171 & 6.50 \\
\hline Mideast Region & 28,721 & 9.1 & 1,307 & 4.55 \\
\hline Federal District & 4,576 & 18.7 & 191 & 4.17 \\
\hline Mato Grosso & 5,301 & 8.1 & 225 & 4.24 \\
\hline Goiás & 11,230 & 6.8 & 528 & 4.70 \\
\hline Mato Grosso do Sul & 7,614 & 7.4 & 363 & 4.77 \\
\hline
\end{tabular}

Source: Datasus.

Regarding the states, Sergipe recorded the highest average mortality rate in Brazil (6.83\%). When considering age groups individually, $75.3 \%$ of deaths occurred in the population aged 80 and over, with a $10.25 \%$ mortality rate. Men in this age group had a higher death rate, $12.29 \%$, more twice of the national average under the same conditions (8.96\%). Santa Catarina has the highest mortality rate under the same conditions (13.03\%). Alagoas and Bahia stand out, despite the lower than average mortality, the mortality rate is higher among women over 80 years old, $4.1 \%$ and $4.41 \%$, comparing with other states, as shown in Table 5.
The average cost per hospitalization in the Southern Region $(\mathrm{R} \$ 2,491)$ was higher than the national average, due to the higher value for hospitalization in the states of Paraná $(R \$ 2,795.62)$ and Santa Catarina ( $R \$ 2,725.61)$. In these, filtering by age groups and sex, the highest cost in hospitalizations over 80 years old occurs among men ( $R \$ 3,018.09$ and $R \$ 2,867.63$, respectively). Cost of 21\% (Paraná) and 27\% (Santa Catarina) higher than the national average for the same sex and age group ( $R \$ 2,376.01)$, also shown in Table 5 
Table 5. Number of hospitalizations, total and average hospitalization, number of deaths and mortality rate, by sex, in the population aged 80 and over, by region/state, Sul and Northeast from 2008 to 2018.

\begin{tabular}{|c|c|c|c|c|c|c|}
\hline Sex & Age Group & $\begin{array}{l}\text { Hospitalizations } \\
\text { (n) }\end{array}$ & $\begin{array}{l}\text { Total Cost } \\
\text { (R\$) }\end{array}$ & $\begin{array}{c}\text { Hospitalization } \\
\text { Average Cost (R\$) }\end{array}$ & Deaths (n) & $\begin{array}{c}\text { Mortality Rate } \\
(\%)\end{array}$ \\
\hline & Total & 18,024 & $49,126,435.18$ & $2,725.61$ & 1,171 & 6.5 \\
\hline Female & 80 years old and over & 6,448 & $17,892,549.71$ & $2,774.90$ & 572 & 8.87 \\
\hline \multicolumn{7}{|c|}{ State: Paraná } \\
\hline & Total & 33,324 & $93,161,247.99$ & $2,795.62$ & 1,946 & 5.84 \\
\hline Female & 80 years old and over & 10,919 & $32,434,056.18$ & $2,970.42$ & 892 & 8.17 \\
\hline \multicolumn{7}{|c|}{ State: Rio Grande do Sul } \\
\hline & Total & 39,164 & $83,187,062.01$ & $2,124.07$ & 1,699 & 4.34 \\
\hline Male & 80 years old and over & 3,680 & $8,121,912.65$ & $2,207.04$ & 335 & 9.1 \\
\hline Female & 80 years old and over & 15,415 & $32,596,898.39$ & $2,114.62$ & 835 & 5.42 \\
\hline \multicolumn{7}{|c|}{ State: Alagoas } \\
\hline & Total & 5,765 & $10,405,461.29$ & $1,804.94$ & 146 & 2.53 \\
\hline Male & 80 years old and over & 758 & $1,319,245.37$ & $1,740.43$ & 22 & 2.9 \\
\hline Female & 80 years old and over & 1,977 & $3,686,575.29$ & $1,864.73$ & 81 & 4.1 \\
\hline \multicolumn{7}{|c|}{ State: Sergipe } \\
\hline & Total & 4,449 & $9,117,137.19$ & $2,049.26$ & 304 & 6.83 \\
\hline Male & 80 years old and over & 586 & $1,233,046.04$ & $2,104.17$ & 72 & 12.29 \\
\hline Female & 80 years old and over & 1,648 & $3,506,065.87$ & $2,127.47$ & 157 & 9.53 \\
\hline \multicolumn{7}{|c|}{ State: Bahia } \\
\hline & Total & 21,058 & $45,114,541.03$ & $2,142.39$ & 920 & 4.37 \\
\hline & Total & 8,174 & $9,463,191.36$ & $2,191.68$ & 244 & 3.51 \\
\hline Male & 80 years old and over & 1,120 & $2,505,247.24$ & $2,236.83$ & 63 & 5.63 \\
\hline Female & 80 years old and over & 3,145 & $6,913,466.57$ & $2,198.24$ & 117 & 3.72 \\
\hline \multicolumn{7}{|c|}{ State: Pernambuco } \\
\hline & Total & 17,427 & $39,302,298.70$ & $2,255.25$ & 548 & 3.14 \\
\hline Male & 80 years old and over & 2,095 & $4,550,246.74$ & $2,171.96$ & 122 & 5.82 \\
\hline Female & 80 years old and over & 6,220 & $14,128,881,19$ & $2,271.52$ & 255 & 4.1 \\
\hline \multicolumn{7}{|c|}{ State: Piauí } \\
\hline & Total & 6,666 & $12,598,755.69$ & $1,890.00$ & 261 & 3.92 \\
\hline Male & 80 years old and over & 832 & $1,653,334.90$ & $1,987.18$ & 88 & 6.73 \\
\hline Female & 80 years old and over & 2,344 & $4,481,404.60$ & $1,911.86$ & 173 & 5.38 \\
\hline \multicolumn{7}{|c|}{ State: Rio Grande do Norte } \\
\hline & Total & 6,554 & $15,888,204.17$ & $2,424.20$ & 211 & 3.22 \\
\hline Male & 80 years old and over & 890 & $2,246,935.87$ & $2,524.65$ & 44 & 4.94 \\
\hline Female & 80 years old and over & 2,674 & $6,770,452.81$ & $2,531.96$ & 105 & 3.93 \\
\hline
\end{tabular}

Source: Datasus.

\section{DISCUSSION}

There are limitations of ecological studies regarding the low applicability at their individual level about the associations between exposure and outcome, and risk for possible confounding variables. ${ }^{11}$ Despite the need for proper registration, the information systems of the Unified Health System (SUS) are powerful tools that guide analyses regarding the punctual or time series situational diagnosis. Moreover, it can base hypothesis of association of variables of interest of the subject, 
stimulating the elaboration of new studies. ${ }^{12}$ In addition, studies estimate that $15 \%$ of the Brazilian population does not use the SUS service, which may result in underestimated data for the total population. ${ }^{13}$ The profile is compatible with the epidemiological for osteoporosis fractures. ${ }^{8,9}$ A population-based study conducted with 4,332 women in the metropolitan region of São Paulo between 2004 and 2007 showed that advanced age, menopause, previous low impact fracture and current smoking were the main risk factors associated with osteoporosis and fractures. The study also showed a $33 \%$ and $11.5 \%$ prevalence of osteoporosis and bone fragility fractures, respectively. ${ }^{14}$

The reason of the difference in regionalization about the occurrence of fractures in older adults cannot be confirmed by the methodology of our study. However, there is a possibility of discussion regarding the aspects involved with the multifactoriality of the event, such as ethnic patterns, eating habits, climate and urbanization, related to hypovitaminosis D, mobility conditions, social protection, access to the health system, notifications of the disease and life expectancy., 8

The Northeast Region had the lowest mortality rate due to femur fracture in Brazil, except in the state of Sergipe, especially in older men. A study conducted in Sobral, Ceará, also identified a low incidence rate of hip fractures among a population living in an equatorial area. ${ }^{15}$

Studies show a $20 \%$ overall mortality rate within 12 months after hip fracture. Although the overall prevalence of fragility fractures is higher in women, men generally have higher fracture-related mortality rates. ${ }^{16}$
The American literature considers the treatment of hip fracture has improved in the last 20 years. Advanced surgical devices and movement toward replacement arthroplasty, early mobilization, better use of prophylactic antibiotics and aggressive medical management may have contributed to improvements in mortality. ${ }^{17}$ These factors impact hospitalization and treatment costs. The southern states presented the highest average costs during the study period, with an increase when selected by sex and age group. Some studies conducted in this location reveal the Caucasian population, with longer life expectancy and risk factors for fracture incidence, as well as the profile of how femur fracture care is performed in older adults. Thus, economic factors may play a significant role in the health of this population. However, the behavior of the three states is shown to be individual when associated with means of permanence and mortality rate. ${ }^{18,19,20}$

\section{CONCLUSION}

The analysis performed in our study showed agreement between population aging, assessed by population projections, and fracture incidence. The highest occurrence of the event occurred in older women in the southeastern and southern states, and the lowest incidence was in the north and northeast regions. Longer stay in the Midwest and higher cost in the South. It is an important cause of mortality and functional loss among older adults, presenting a higher incidence in men over 80 years. The evaluation and monitoring of this indicator are important, considering the differences between the regions of Brazil, with consequences for the individual and economic for health systems.

AUTHORS' CONTRIBUTIONS: Each author contributed individually and significantly to the development of this article: VCUP: data analysis, writing and review; JCGJ: data collection, graphs and article review; WDJ: statistical analysis, tables and article review; AVL: statistical analysis and article review; PEBJ: writing and review; MRCGN: article design, statistical analysis and article writing and review.

\section{REFERENCES}

1. He W, Goodkind D, Kowal P. An aging world: 2015. Washington, DC: U. S. Government Publishing Office; 2016.

2. Instituto Brasileiro de Geografia e Estatística. Projeções da população: Brasil e unidades da Federação: revisão 2018. Rio de Janeiro; 2018.

3. Massa KHC, Duarte YAO, Chiavegatto Filho ADP. Análise da prevalência de doenças cardiovasculares e fatores associados em idosos, 2000-2010. Ciênc Saúde Colet. 2019;24(1):105-14.

4. Bauer UE, Briss PA, Goodman RA, Bowman BA. Prevention of chronic disease in the 21st century: elimination of the leading preventable causes of premature death and disability in the USA. Lancet [Internet]. 2014 [cited 2020 Jan 8];384(9937):45-52. Available from: http://bit.ly/2sYILaW

5. Theme Filha MM, Souza Junior PRB, Damacena GN, Szwarcwald CL. Prevalência de doenças crônicas não transmissíveis e associação com autoavaliação de saúde: Pesquisa Nacional de Saúde, 2013. Rev Bras Epidemiol. [Internet]. 2015 [cited 2020 Jan 8];18(suppl 2):83-96. Available from: http://bit.ly/304JeUV

6. Beaudart C, Rolland Y, Cruz-Jentoft AJ, Bauer JM, Sieber C, Cooper C, et al. Assessment of muscle function and physical performance in daily clinical practice. Calcif Tissue Int [Internet]. 2019 [cited 2020 Jan 8];105(1):1-14. Available from: http://bit.ly/39QKDTS

7. Harvey NC, Odén A, Orwoll E, Lapidus J, Kwok T, Karlsson MK, et al. Falls predict fractures independently of FRAX probability: a meta-analysis of the osteoporotic fractures in men (MrOS) study. J Bone Miner Res. 2018;33(3):510-6.

8. Kanis JA, Odén A, McCloskey EV, Johansson H, Wahl DA, Cooper C. A systematic review of hip fracture incidence and probability of fracture worldwide. Osteoporos Int. 2012;23(9):2239-56.

9. Bliuc D, Nguyen ND, Milch VE, Nguyen TV, Eisman JA, Center JR. Mortality risk associated with low-trauma osteoporotic fracture and subsequent fracture in men and women. JAMA [Internet]. 2009 [cited 2020 Jan 8];301(5):513-21. Available from: http://bit.ly/2T5oCuz
10. Zerbini CA, Szejnfeld VL, Abergaria BH, McCloskey EV, Johansson H, Kanis JA. Incidence of hip fracture in Brazil and the development of a FRAX model. Arch Osteoporos. 2015;10:224.

11. Skelly AC, Dettori JR, Brodt ED. Assessing bias: the importance of considering confounding. Evid Based Spine Care J [Internet]. 2012 [cited 2020 Jan 8];3(1):912. Available from: http://bit.ly/2FvGXsz

12. Bittencourt SA, Camacho LAB, Leal MC. O sistema de informação hospitalar e sua aplicação na saúde coletiva. Cad Saúde Pública [Internet]. 2006 [cited 2020 Jan 8];22(1):19-30. Available from: http://bit.ly/2tL2M4D

13. Silva PLB. Serviços de saúde: o dilema do SUS na nova década. São Paulo Perspec. 2003;17(1):69-85.

14. Pinheiro MM, Reis Neto ET, Machado FS, Omura F, Yang JHK, Szejnfeld J, et al. Risk factors for osteoporotic fractures and low bone density in pre and postmenopausal women. Rev Saude Pública [Internet]. 2010 [cited 2020 Jan 8];44(3):47985. Available from: http://bit.ly/2QWeCRr

15. Rocha FAC, Ribeiro AR. Low incidence of hip fractures associated with osteoporosis in Sobral-CE. Rev Bras Reumatol. 2004;44(4):255-8.

16. Kannegaard PN, van der Mark S, Eiken P, Abrahamsen B. Excess mortality in men compared with women following a hip fracture. National analysis of comedications, comorbidity and survival. Age Ageing [Internet]. 2010 [cited 2020 Jan 8];39(2):203-9. Available from: http://bit.ly/2tKb2BS

17. Brauer CA, Coca-Perraillon M, Cutler DM, Rosen AB. Incidence and mortality of hip fractures in the United States. JAMA. 2009;302(14):1573-9.

18. Silva DMW, Borba VZC, Kanis JA. Evaluation of clinical risk factors for osteoporosis and applicability of the FRAX tool in Joinville City, Southern Brazil. Arch Osteoporos. 2017;12(1):111.

19. Oliveira CC, Borba VZC. Epidemiology of femur fractures in the elderly and cost to the state of Paraná, Brazil. Acta Ortop Bras. 2017;25(4):155-8.

20. Madeiras JG, Silva ES, Yamaguchi MU, Bertolini SMMG, Costa CKF, Christofel $\mathrm{HK}$, et al. Determinantes socioeconômicos e demográficos na assistência à fratura de fêmur em idosos. Ciênc Saúde Colet. 2019;24(1):97-104. 